\title{
PENGARUH PROFESIONALITAS, KEPUASAN KERJA DAN IKLIM ORGANISASI TERHADAP KINERJA GURU SMKN DI KABUPATEN BOYOLALI
}

\author{
Widyanggoro Pamungkas, Cepi S. Abdul Jabar \\ SDN Gendongan 01, Universitas Negeri Yogyakarta \\ widyanggorop@yahoo.com, cepi_Safruddin@uny.ac.id
}

\begin{abstract}
Abstrak
Penelitian ini bertujuan untuk mengetahui pengaruh profesionalitas, kepuasan kerja, dan iklim organisasi secara parsial maupun bersama-sama terhadap kinerja guru di ring utara Kabupaten Boyolali.Penelitian ini menggunakan pendekatan kuantitatif dengan jenis penelitian korelasional. Populasi penelitian adalah seluruh guru SMK Negeri di ring utara Kabupaten Boyolali yang berjumlah 180 orang. Tehnik pengambilan sampel dengan proportional random sampling sebanyak 119 orang yang tersebar di SMK Negeri di ring utara .Pengumpulan data dilakukan dengan memberikan angket kepada guru SMK Negeri di ring utara. Teknik analisis data yang digunakan adalah regresi linear dan regresi ganda dengan taraf signifikansi 0,05 . Semua pengujian dalam penelitian ini menggunakan bantuan program SPSS versi 17.Hasil penelitian ini menunjukkan bahwa terdapat pengaruhsecara parsial profesionalitas $\left(\mathrm{r}^{2}=12,4 \%\right)$, kepuasan kerja $\left(\mathrm{r}^{2}=11,2 \%\right)$ dan iklim organisasi $\left(\mathrm{r}^{2}=7,7 \%\right)$ terhadap kinerja guru, dan secara bersama-sama pengaruhnya $\left(R^{2}\right)$ sebesar $22,3 \%$.
\end{abstract}

Kata Kunci: profesionalitas, kepuasan kerja, iklim organisasi, kinerja

\section{THE INFLUENCE OF PROFESSIONALISM, JOB SATISFACTION AND ORGANIZATIONAL CLIMATE ON PERFORMANCE OF SMKN IN BOYOLALI}

\begin{abstract}
This study aimed to determine the effect of teacher professionalism, job satisfaction, and organizational climate partially and simultaneously on the performance of teachers in the northern region Boyolali. This study used a quantitative approach with the type of correlational research. The study population was all teachers of SMK Negeri in the northern region Boyolali totaling 180 people. The sampling technique was proportional random sampling as many as 119 people. Data collection was conducted by giving questionnaires to teachers of SMK Negeri in the northern region Boyolali. The data analysis technique used was linear regression and multiple regression with a significance level of 0.05 . All tests in this study used SPSS version 17. The results of this study indicate that there effect partially of professionalism $(r 2=12,4 \%)$, job satisfaction $(r 2=11,2 \%)$ and organizational climate $(r 2=7,7 \%)$ on the performance of teachers, and in aggregate the influence (R2) of 22,3\%.
\end{abstract}

Keywords: professionalism, job satisfaction, organizational climate, performance 


\section{Pendahuluan}

Mutu pendidikan salah satunya berpangkal dari persoalan guru, hal ini wajar karena guru dipandang sebagai sumber daya yang aktif dibanding komponen organisasi sekolah yang lain, seperti sarana prasarana dan kurikulum yang merupakan sumber daya pasif. Guru merupakan salah satu faktor penentu keberhasilan pendidikan, itulah sebabnya setiap adanya upaya peningkatan mutu pendidikan, selalu bermuara pada guru. Guru merupakan salah satu faktorpenentu tinggi rendahnya mutu hasil pendidikan, maka setiap usaha peningkatan mutu pendidikan perlu memberikan perhatian besar kepada peningkatan kinerja guru. Guru dituntut memiliki kinerja yang mampu memberikan dan merealisasikan harapan dan keinginan semua pihak terutama masyarakat umum yang telah mempercayai sekolah dan guru dalam membina anak didik. Untuk meraih mutu pendidikan yang baik sangat dipengaruhi oleh kinerja guru dalam melaksanakan tugasnya sehingga kinerja guru menjadi tuntutan penting untuk mencapai keberhasilan pendidikan.

Peningkatan kinerja guru tidak semata-mata hanya meningkatkan kompetensinya baik melalui pemberian penataran, pelatihan maupun pemberian kesempatan untuk lebih berkembang namun perlu juga memperhatikan guru dari segi yang lain seperti profesionalisme guru, pemberian insentif, gaji yang layak, sehingga memungkinkan guru menjadi puas dalam bekerja sebagai pendidik, dan budaya iklim organisasi yang kondusif sehingga dalam suasana bekerja menjadi nyaman.

Salah satu hal yang patut dipertimbangkan adalah bagaimana upaya untuk meningkatkan kualitas guru adalah dengan cara meningkatkan kepuasan kerjanya, sebab dengan kepuasan guru yang meningkat maka guru akan berusaha untuk meningkatkan profesi dan mutunya dengan demikian diharapkan keberhasilan pendidikan akan tercapai. Kepuasan kerja guru itu bisa dilaksanakan dengan beberapa cara diantaranya adalah organisasi dapat membuat iklim organisasi yang berpihak pada kesejahteraan guru, terbuka dan menekankan pada prestasi, karena hal tugas guru menyangkut dengan keberhasilan siswa yang merupakan keberhasilan pendidikan.

Kinerja dipengaruhi oleh banyak faktor dan salah satu diantaranya adalah iklim organisasi. Hal ini didasarkan pada asumsi bahwa para guru bekerja selain untuk mengharapkan imbalan baik material maupun non-material namun mereka juga menginginkan iklim yang sesuai dengan harapan mereka seperti terdapat keterbukaan dalam organisasi, terdapat perhatian, dukungan, penghargaan, pendapatan yang layak dan dirasa adil. Penciptaan iklim yang berorientasi pada prestasi dan mementingkan pekerja dapat memperlancar pencapaian hasil yang diinginkan.

Kebijakan pemerintah saat ini sedang meningkatan pertumbuhan SMK baik secara kualitas maupun kuantitas, SMK Negeri ring utara ini merupakan sekolah yang baru berdiri rata-rata kurang dari 10 tahun, jadi bisa dikatakan sekolah baru yang rata-rata sarana prasarana kegiatan belajar mengajar yang masih kurang lengkap, kegiatan belajar mengajar lebih didominasi oleh guru-guru wiyata karena jumlah perbandingan antara guru wiyata dan PNS lebih banyak guru wiyata, letak geografis jauh dari kota dan jarak tempuh guru ke sekolahan cukup jauh, sehingga mempengaruhi kinerja guru. Pada tahun 2013 nilai rata-rata Ujian Nasional untuk tiga mata pelajaran yang diujikan SMK Negeri ring utara sebesar sebesar 6,725, hal ini menunjukkan pestasi siswa belum optimal atau relatif rendah, salah satu kemungkinan penyebab yang adalah kinerja guru yang belum optimal.

Dari uraian tersebut nampak bahwa profesionalitas, kepuasan kerja, dan iklim organisasi bersinergi untuk menciptakan kinerja guru. Dalam mewujudkan harapan tersebut, penelitian ini memiliki tujuan untuk mengetahui pengaruh profesionalitas, kepuasan kerja, dan iklim organisasiterhadap kinerja guru di SMK Negeri di ring utara kabupaten Boyolali. Manfaat 
dari penelitian ini memberikan alternatif pemecahan masalah kinerja guru dan masukan bagi lembaga pendidikan khususnya SMK Negeri di ring utara kabupaten Boyolali.

Lunenburg \& Ornstein (2000, p.88) mengatakan, "School administrators widely agree that motivation is a critical determinant of performance in organization,...". Secara umum administrator sekolah secara luas sepakat bahwa motivasi merupakan suatu faktor penentu kinerja dalam organisasi sekolah.Motivasi seorang guru dalam bekerja mendorong mereka mengalahkan kesulitan-kelsulitan yang dihadapi, dan menganggap ringan beban-beban diri yang menghambat dalam bekerja.

Mitchell (Wahyudi, 2012, p.130) mengatakan faktor-faktor yang mempengaruhi kinerja adalah: (1) kualitas kerja, kualitas kerja yang baik menunjukkan bahwa seorang tersebut memiliki kinerja yang baik. Sebaliknya apabila kualitas pekerjaannya jelek maka kinerjanya lemah. (2) ketepatan, seseorang yang dapat bekerja dengan tepat sesuai dengan petunjuk yang seharusnya dan didukung dengan kecepatan seseorang dalam bekerja, menandakan bahwa seseorang tersebut memiliki kinerja yang baik. Seseorang yang kinerjanya baik, mampu bekerja dengan tepat, cepat dan rapi. (3) inisiatif, seseorang yang memiliki kinerja yang tinggi memiliki inisiatif yang baik dalam melaksanakan setiap tugas dan tanggung jawab yang dibebankan kepadanya. Ia memanfaatkan potensi pikirannya untuk senantiasa menemukan kreatifitaskreatifitas baru yang dapat meningkatkan hasil kerjanya, memiliki ide-ide, temuantemuan. Orang seperti ini banyak belajar baik dari buku maupun bertanya. (4) kapabalitas, tingkat kerja yang baik diamati dari kapabalitas. Seseorang yang mempunyai kemampuan yang baik, akan dapat menyelesaikan semua permasalahan yang muncul dalam pekerjaannya dengan baik dan senang menerima banyak tantangan. (5) komunikasi, seseorang yang tingkat kinerjanya tinggi, dapat berkomunikasi dengan baik. Baik dengan atasan, bawahan maupun dengan teman sejawat.
Konsep kinerja guru (Rusman, 2010, p.50) sebagai cara kerja yang menyangkut kemampuan melaksanakan tugas mengajar dapat dilihat dari indikator: kemampuan merencanakan program belajar mengajar, kemampuan melaksanakan/mengelola proses belajar mengajar, dan kemampuan menilai proses belajar mengajar.

Selanjutnya, Dalam Jurnal Hong Kong Teachers' Centre, Chan (2004, p.56) menyimpulkan bahwa The professional development of teachers can be considered in two aspects: cognitive and affective, both of which are important in determining teachers' efficacy. The cognitive aspect refers to acquisition of pedgagogical knowledge and improved instructional skill, which will help teachers' classroom teaching and management. Pengembangan profesional guru dapat dipertimbangkan dalam dua aspek: kognitif dan afektif dalam menentukan keberhasilan guru. Aspek kognitif mengacu pada akuisisi pengetahuan pedagogik dan peningkatan instruksional keterampilan, yang akan membantu pengajaran di kelas guru dan manajemen.

Sedangkan Yamin $(2007$, p.14) mengidentifikasi ciri-ciri profesionalitas sebagi berikut: (1) seseorang professional menggunakan waktu penuh untuk menjalankan pekerjaannya, (2) terikat oleh panggilan hidup yang dalam hal ini memberlakukan pekerjannya sebagai perangkat norma kepatuhan dan perilaku, (3) merupakan anggota organisasi professional yang formal, (4) menguasai pengetahuan yang berguna dan ketrampilan atas dasar latihan spesialisasi atau pendidikan yang sangat khusus, (5) terikat pada syarat-syarat kompetensi, kesadaran prestasi dan pengabdian, dan (6) memperoleh otonomi berdasarkan spesialisasi teknis yang tinggi sekali.

Dengan demikianbahwa seorang profesional akan selalu mengadakan pelayanan atau mengabdi dilandasi kemampuan profesional serta filsafat yang mantap. Artinya seorang profesional akan menampakkan adanya ketrampilan teknis yang didukung oleh pengetahuan dan sikap kepribadian tertentu serta dilandasi oleh norma-norma yang mengatur perilaku anggota-anggota profesi. 
Snoek (2012, p.9) merumuskan elemen-elemen yang akan mendukung profesionalitas guru sebagai berikut:Elemen yang berkontribusi terhadap profesionalitas guru; pengetahuan mendalam tentang pelajaran, pengetahuan yang mendalam tentang proses belajar mengajar (termasuk yang up to date dengan hasil yang relevan dari penelitian pendidikan), pengetahuan mendalam tentang masyarakat, pengetahuan tentang kebijakan danorganisasi dalam pendidikan. Keterampilan: mampu berkomunikasi dan mendiskusikan isu-isu pendidikan dengan khalayak yang lebih luas, mampu memperhitungkan kualitas pekerjaan ke dunia luar, mampu melakukan penelitian dalam praktek sekolah, mampu memberikan kontribusi untuk pembelajaran kolaboratif masyarakat profesional, mampu menerjemahkan hasil penelitian pendidikan untuk inovasi dalam kelas/sekolah. Sikap: didedikasikan untuk belajar siswa, berkomitmen untuk profesi dan kelompok kolektif profesional, bersedia untuk berkontribusi pada pengetahuan kolektif profesi, berkomitmen untuk kode etik profesi dan integritas/pekerjaannya, bersedia untuk memperhitungkan kualitas pekerjaan ke dunia luar, berfokus pada pengembangan profesional berkelanjutan, fokus pada perbaikan dan inovasi pengajaran.

Kemampuan yang terkait dengan pemberian umpan balik (feedback) dan penguatan (reinforcement). Kemampuan tersebut ditunjukkan dengan memberikan umpan balik yang positif terhadap respon siswa, memberikan respon yang bersifat membantu terhadap siswa yang lamban belajar. Guru mampu memberikan tindak lanjut terhadap jawaban siswa yang kurang memuaskan. Guru mampu memberikan bantuan profesional kepada siswa jika diperlukan.

Guru sebagai pegawai harus selalu mendapatkan kesempatan dan dorongan secara kuat untuk terus melakukan pekerjaannya secara profesional. Mengingat bahwa profesionalitas seorang guru memiliki dampak yang luas terhadap keberhasilan pendidikan, dan tentu saja profesionalitas seorang guru akan berpengaruh terhadap kinerja guru yang bersangkutan maupun terhadap kinerja pegawai yang lain.

Sedangkan kepuasan kerja menurut Robin (Mbah \& Ikemefuna, 2012: 2) ada-lah "a general attitude towards an individual's job, and the difference between the amount of reward workers receive and the amount they believe they should receive." Kepuasan kerja adalah sikap umum terhadap pekerjaan seseorang, dan perbedaan antara jumlah pekerja menerima upah dan jumlah yang mereka percaya bahwa mereka harus menerima.

Selanjutnya menurut Damin (2008, p.218) mengemukakan bahwa: kepuasan kerja merupakan kombinasi aspek ekonomis, psikologis, sosiologis, kultural, aktualisasi diri, penghargaan dan suasana lingkungan. Kombinasi yang serasi tersebut menyebabkan seseorang menyatakan "Saya puas dengan pekerjaan saya". Dengan demikian, kepuasan kerja dapat diberikan makna sebagai orientasi sikap individu untuk berperan dalam pekerjaan yang sedang ditekuni.

McPheat (2010, p.24) menawarkan beberapa konsep agar pimpinan atau guru di lembaga manapun memiliki kepuasan kerja yang baik, maka hendaknya mereka memiliki kompetensi emosi yang baik. Kompetensi emosi yang dimaksud adalah sebagaimana yang diteorikan oleh Goleman yang meliputi self awareness, self management, social awareness, and social skills. Mengenali emosi diri akan menuntun seseorang untuk menyadari kondisi emosi yang dimiliki. Dengan mengenali emosi, maka ketidakpuasan akan bisa lebih ditekan. Ketidakpuasan guru terhadap pekerjaan akan menurunkan derajat kinerja yang dilakukan guru.Sementara semakin seseorang menguasai diri, mengenali emosinya, maka seorang guru akan mampu terus berkarya dan melaksanakan pekerjaannya dengan suka cita.

Kepuasan kerja guru yang senantiasa bisa dijaga pada setiap personal di dalam organisasi, maka akan menciptakan pula iklim organisasi yang kondusif. Iklim organisasi di suatu lembaga sekolah sangat berkaitan erat bagaimana seorang guru atau kepala sekolah sanggup bekerja secara 
maksimal. Hal demikian menunjukkan adanya kinerja yang bagus di lembaga tersebut. Selain kondisi atau iklim yang bagus dalam sebuah lembaga yang akan meningkatkan kepuasan kerja seorang pegawai, bahwa faktor pemimpin merupakan aspek yang akan mempengaruhi tingkat kepuasan pegawai yang menjadi bawahannya.

Selanjutnya R. Tangiuri \& G. Litwin (Wirawan, 2008, p.121) mendefinisikan iklim organisasi sebagai,... a relatively enduring quality of the internal environment of an organization that (a) is experienced by it's member, (b) influences their behavior, and can be described in trems of the values of $a$ particular set of characteristic (or attributes) of organization. Iklim organisasi disampaikan sebagai kualitas lingkungan internal suatu organisasi yang dipengaruhi oleh anggotanya dan mempengaruhi perilaku mereka, dan dapat dijelaskan dalam bentuk nilainilai dari seperangkat karakteristik atau atribut dari organisasi.

Sedangkan Litwin \& Stringers $(\mathrm{Mu}-$ hammad, 2006,p.83) memberikan dimensi iklim organisasi yang terdiri dari: “(1) rasa tanggung jawab, (2) standard atau harapan tentang kualitas pekerjaan, (3) penghargaan atau reward, (4) rasa persaudaraan, dan (5) semangat tim." Pendapat tersebut lebih menekankan pada hal-hal yang bersifat positif dan membangun. Iklim organisasi yang dimaknai dengan makna-makna yang akan meningkatkan produktifitas kerja pada suatu lembaga atau sekolah.

Hoy \& Miskel (2001,p.200) membagi iklim organisasi menjadi dua macam yaitu: The open cilmate dan the closed climate. "The open climate is marked by cooperation and respect within the factually and between the faculty and principal. The closed cilmate is virtually the antithesis of the open climate". Iklim organisasi yang terbuka yaitu ditandai dengan adanya kerjasama yang baik dan respek terhadap lingkungan secara nyata antara warga sekolah dengan kepala sekolah. Adapun iklim organisasi yang tertutup menunjukkan hal yang sebaliknya dengan iklim organisasi yang terbuka. Kerja-kerja di sekolah hanya merupakan rutinitas, kurang adanya kerjasama dan respek dari warga sekolah.

\section{Metode Penelitian}

Jenis Penelitian

Penelitian ini merupakan penelitian kuantitatif. Jenis yang digunakan dalam penelitian ini adalah korelasional, yaitu penelitian yang dirancang untuk menentukan tingkat hubungan variabel-variabel yang berbeda dalam suatu populasi

Tempat dan Waktu Penelitian

Penelitian ini mengambil tempat di semua SMK Negeri di ring utara Kabupaten Boyolali. Sedangkan pelaksanaan penelitian dilaksanakan dari bulan Oktober 2013 sampai Januari 2014.

Populasi dan Sampel Penelitian

Populasi yang digunakan dalam penelitian ini adalah seluruh guru dari SMK Negeri di ring utara kabupaten Boyolali yang terdiri dari 4 SMK Negeri

Sampel penelitian 4 SMK Negeri yang dipilih dengan teknik proportional random sampling, adapun narasumber/responden adalah guru.

Variabel Penelitian

Variabel Terikat (Dependent Variable) Kinerja $\operatorname{Guru}(Y)$

Kinerja guru adalah prestasi diperoleh dari penilaian cara kerja guru yang direpresentasikan dalam kemampuan melaksanakan tugas mengajar yang meliputi: (1) kemampuan, merencanakan proses belajar mengajar, (2) kemampuan mengelola proses belajar mengajar, dan (3) kemampuan menilai proses belajar mengajar.

Variabel bebas (Independent Variable)

Profesionalitas $\left(\mathrm{X}_{1}\right)$

Profesionalitas guru adalah suatu sikap yang dilandasi ketrampilan teknis yang didukung oleh pengetahuan dan sikap kepribadian tertentu serta dilandasi 
oleh norma-norma yang mengatur perilaku anggota-anggota profesi.

Kepuasan Kerja $\left(\mathrm{X}_{2}\right)$

Kepuasan kerja guru adalah keadaan emosional yang menyenangkan atau tidak menyenangkan bagi para karyawan dalam memandang pekerjaan mereka.

Iklim Organisasi $\left(X_{3}\right)$

Iklim organisasi sekolah adalah penilaian pada suasana atau lingkungan kerja dalam penilaian dan persepsi dalam hal: (1) struktur organisasi, (2) gaya kepemimpinan, dan (3) hubungan antar personil.

Dari kriteria tersebut, dibuat skor menggunakan skala likert, kemudian dikelompokkan menggunakan distribusi frekuensi berdasarkan kelas interval dan diberi kriteria menyesuaikan jenis instrumen.

Teknik Pengumpulan Data

Teknik pengumpulan data dalam penelitian ini yaitu kuisioner yang menggunakan pernyataan tertutup dengan validitas item yang mendapat pertimbangan ahli dan uji empirik, sedangkan reliabilitas instrumen dengan teknik Alpha_Cronbach.

Adapun pengambilan keputusan pada uji validitas dengan menggunakan batasan $r$ tabel, dengan signifikansi 0,05 atau menggunakan batasan 0,361 pada $\mathrm{n}=$ 119. Hasil uji validitas instrumen variabel kinerja guru dari jumlah 23 item pertanyaan angket menunjukkan 22 item yang dianggap valid, instrumen variabel profesionalitas19item pertanyaan angket menunjukkan 19 item dinyatakan valid, kemudian instrumen kepuasan kerja dari 17 item pertanyaan angket menunjukkan 15 item dinyatakan valid, dan variabel iklim organisasi dari 9item pertanyaan angket menunjukkan 9 item dinyatakan valid.

Selanjutnya untuk uji reliabilitas, harga kritik untuk indeks reliabilitas instrumen adalah 0,60 hal ini berarti suatu instrumen dikatakan reliabel apabila memiliki alpha $>0,60$. Adapun hasil reliabiltas instrumen disajikan pada Tabel 1.
Tabel 1. Hasil Reliabilitas Instrumen

\begin{tabular}{lcl}
\hline Variabel & $\begin{array}{c}\text { Cronbach's } \\
\text { Alpha }\end{array}$ & Keterangan \\
\hline Kinerja guru & 0,962 & Reliable \\
$\begin{array}{l}\text { Profesionalitas } \\
\text { kerja guru }\end{array}$ & 0,970 & Reliable \\
$\begin{array}{l}\text { Kepuasan guru } \\
\text { Iklim }\end{array}$ & 0,882 & Reliable \\
organisasi & 0,914 & Reliable \\
\hline
\end{tabular}

Berdasar tabel di atas semua instrumen dinyatakan reliabel. Untuk itu semua instrumen yang dinyatakan valid dan reliabel sudah layak digunakan untuk mengambil data.

Teknis Analisis Data

Uji Persyaratan Analisis

Uji Normalitas

Uji normalitas (Ghozali, 2001,p. 83) digunakan untuk mengetahui apakah penyebaran data memenuhi asumsi normal. Dengan bantuan SPSS, dengan menggunakan model One-Sample KolmogorovSmirnov Test, maka akan diketahui normal atau tidaknya suatu penyebaran data. Kaidah keputusannya adalah apabila Asymp. Sig. (2-tailed) menunjukkan angka > 0,05 maka data dinyatakan normal.

\section{Uji Linearitas}

Linearitas (Ghozali, 2001,p.63) adalah sifat hubungan yang linear antar variabel, artinya setiap perubahan yang terjadi pada satu variabel akan diikuti perubahan dengan besaran yang sejajar pada variabel lainnya. Kaidah keputusannya adalah apabila nilai SigTest of Linearity pada output SPSS kurang dari 0,05, maka data dinyatakan linear.

\section{Uji Autokorelasi}

Uji autokorelasi (Ghozali, 2001, p.67) digunakan untuk mengetahui ada atau tidaknya penyimpangan asumsi klasik autokorelasi yaitu korelasi yang terjadi antara residual pada satu pengamatan dengan pengamatan lain pada model regresi. Kaidah keputusannya adalah apabila $d u$ (batas atas) pada tabel Durbin waston lebih kecil dari Durbin Waston pada output Model Summary 
Uji Hipotesis

Analisis Regresi Linear Berganda

Analisis regresi linear berganda (Ghozali, 2001, p.44) digunakan untuk mengetahui pengaruh variabel bebas terhadap variabel terikat. Sesuai dengan hipotesis yang disimpulkan dalam tinjauan teoretik maka variabel-variabel yang diteliti dapat disusun dalam persamaan sebagai berikut.

$$
\hat{Y}=a+b_{1} X_{1}+b_{2} X_{2}+b_{3} X_{3}
$$

Keterangan :

$Y=$ nilai yang diprediksi

$\mathbf{X}_{\mathbf{1}}=$ profesionalitas

$\mathbf{X}_{\mathbf{2}}=$ kepuasan kerja

$\mathbf{X}_{3}=$ iklim organisasi

a = bilangan konstan

b = bilangan koefisien prediktor

Analisis Regresi Linear Sederhana

Analisis regresi linear sederhana (Ghozali, 2001, p.44) digunakan untuk mengetahui pengaruh variabel bebas secara parsial terhadap variabel terikat. Sesuai dengan hipotesis yang disimpulkan dalam tinjauan teoritik maka variabelvariabel yang diteliti dapat disusun dalam persamaan sebagai berikut.

$$
\hat{\mathbf{Y}}=\mathbf{a}+\mathbf{b X}
$$

Keterangan :

$\mathrm{Y}=$ nilai yang diprediksi

$\mathrm{X}=$ nilai variabel prediktor

a = bilangan konstan

$\mathrm{b}=$ bilangan koefisien prediktor

\section{Hasil Penelitian dan Pembahasan}

Analisis Deskriptif Variabel Penelitian

Temuan penelitian menunjukkan hasil sebagaimana disajikan pada Tabel 2.

Berdasarkan Tabel 2 dapat dijelaskan bahwa variabel profesionalitas diperoleh mean sebesar 65,9580 dengan standar deviasi sebesar 7,51991. Variabel kepuasan kerja diperoleh mean sebesar 49,5126 dengan standar deviasi sebesar 6,43595, dan variabel iklim organisasi diperoleh mean sebesar 29,8403 dengan standar deviasi sebesar 4,74964, serta variabel kinerja guru diperoleh mean 74,6891 dengan standar deviasi sebesar 8,09975. Secara rinci dengan distribusi frekuensi deskripsi masing-masing variabel dijelaskan sebagai berikut.

Tabel 2. Rangkuman Deskripsi Data Rekapitulasi Data Analisis Frekuensi

\begin{tabular}{lrrrr}
\hline Variabel & $\begin{array}{c}\text { X1: } \\
\text { Deskriptif } \\
\text { Profesi- } \\
\text { onalitas }\end{array}$ & $\begin{array}{c}\text { Kepuasan } \\
\text { Kerja }\end{array}$ & $\begin{array}{c}\text { X3: } \\
\text { Iklim } \\
\text { Organi- } \\
\text { sasi }\end{array}$ & $\begin{array}{c}\text { Y: } \\
\text { Kinerja } \\
\text { Guru }\end{array}$ \\
\hline Mean & 65,9580 & 49,5126 & 29,8403 & 74,6891 \\
Median & 67,0000 & 51,0000 & 30,0000 & 73,0000 \\
Mode & 57,00 & 45,00 & 27,00 & 66,00 \\
Std. Deviation & 7,51991 & 6,43595 & 4,74964 & 8,09975 \\
Range & 27,00 & 41,00 & 27,00 & 34,00 \\
Minimum & 49,00 & 19,00 & 9,00 & 54,00 \\
Maximum & 76,00 & 60,00 & 36,00 & 88,00 \\
Sum & 7849,00 & 5892,00 & 3551,00 & 8888,00 \\
\hline
\end{tabular}

Profesionalitas Guru

Profesionalitas guru SMK Negeri di Ring Utara Kabupaten Boyolali adalah salah satu variabel dengan indikator waktu penuh untuk pekerjaan, keanggotaan organisasi profesi, patuh pada norma dan perilaku, menguasai pengetahuan yang berguna dan ketrampilan atas dasar latihan spesialisasi atau pendidikan yang sangat khusus, terikat pada syarat-syarat kompetensi, dan kesadaran prestasi dan pengabdian.

Pengelompokkan data profesionalitas guru disajikan pada Tabel 3.

Tabel 3. Hasil Analisis Deskriptif Profesionalitas

\begin{tabular}{ccccc}
\hline No & $\begin{array}{c}\text { Kelas } \\
\text { Interval }\end{array}$ & Frekuensi Persentase & Klasifikasi \\
\hline 1 & $49-55$ & 4 & 3,36 & Kurang baik \\
2 & $56-62$ & 43 & 36,13 & Cukup baik \\
3 & $63-69$ & 30 & 25,21 & Baik \\
4 & $70-76$ & 42 & 35,29 & Sangat baik \\
\multicolumn{2}{c}{ Jumlah } & 119 & $100 \%$ & \\
\hline
\end{tabular}

Berdasarkan Tabel 3, mean variabel profesionalitas guru sebesar 65,9580terletak pada interval 63-69 dalam kategori baik. Hal ini mengandung arti bahwa kecenderungan jawaban responden secara ke- 
seluruhan mengarah pada tingkatan baik, dengan demikian, secara keseluruhan profesionalitas guru di SMK Negeri di Kabupaten Boyolalidalam kategori baik.

Kepuasan Kerja

Pengelompokan data kepuasan kerja pembelajaran berikut ini:

Tabel 4. Hasil Analisis Deskriptif Kepuasan Kerja

\begin{tabular}{ccccc}
\hline No & $\begin{array}{c}\text { Kelas } \\
\text { Interval }\end{array}$ & Frekuensi & Persentase & Klasifikasi \\
\hline 1 & $19-32$ & 3 & 2,52 & Rendah \\
2 & $33-46$ & 31 & 26,05 & Sedang \\
3 & $47-60$ & 85 & 71,43 & Tinggi \\
\cline { 3 - 3 } & Jumlah & 119 & $100 \%$ & \\
\hline
\end{tabular}

Berdasarkan Tabel 4. Mean variabel kepuasan kerja sebesar 49,5126 terletak pada interval 47-60dalam kategori tinggi, dengan demikian pengelolaan kepuasan kerja guru di sana tinggi.

Iklim organisasi

Pengelompokan data iklim organisasi disajikan pada Tabel 5 .

Tabel 5. Hasil Analisis Deskriptiflklim Organisasi

\begin{tabular}{ccccl}
\hline No & $\begin{array}{c}\text { Kelas } \\
\text { Interval }\end{array}$ & Frekuensi & Persentase & Klasifikasi \\
\hline 1 & $9-15$ & 3 & $2,52 \%$ & Kurang baik \\
2 & $16-22$ & 0 & $0 \%$ & Cukup baik \\
3 & $23-29$ & 54 & $45,38 \%$ & Baik \\
4 & $30-36$ & 62 & $52,10 \%$ & Sangat baik \\
\multicolumn{2}{c}{ Jumlah } & 119 & $100 \%$ & \\
\hline
\end{tabular}

Pada Tabel 5 mean atau skor rata-rata variabel iklim organisasi sebesar 29,8403 terletak pada interval 23-29 dalam kategori baik, dengan demikian iklim organisasi di sana adalah baik.

\section{Kinerja Guru}

Pengelompokan data kinerja guru di di SMK Negeri di ring utara kabupaten Boyolali dapat dilihat secara rinci disajikan pada Tabel 6 .

Tabel 6. Hasil Analisis Deskriptif Kinerja Guru

\begin{tabular}{|c|c|c|c|c|}
\hline No & $\begin{array}{c}\text { Kelas } \\
\text { Interval }\end{array}$ & Frekuensi & Persentase & Klasifikasi \\
\hline 1 & $54-60$ & 3 & $2,52 \%$ & Sangat rendah \\
\hline 2 & $61-67$ & 22 & $18,49 \%$ & Rendah \\
\hline 3 & $68-74$ & 41 & $34,45 \%$ & Cukup \\
\hline 4 & $75-81$ & 22 & $18,49 \%$ & Tinggi \\
\hline 5 & $82-88$ & 31 & $26,05 \%$ & Tinggi sekali \\
\hline \multicolumn{2}{|c|}{ Jumlah } & 119 & $100 \%$ & \\
\hline
\end{tabular}

Dengan melihat Tabel 2 dan berdasarkan Tabel 6 di atas mean atau skor ratarata variabel kinerja guru sebesar 74,6891 terletak pada interval 68-74 dalam kategori cukup, dengan demikian kinerja guru adalah cukup. Hal ini mengandung arti bahwa kecenderungan jawaban responden secara keseluruhan mengarah pada tingkatan cukup.

Uji Hipotesis Pertama

Hipotesis Pertama, terdapat pengaruh antara profesionalitas terhadap kinerja guru.

Tabel 7. Model Summary Hipotesis pertama

Model Summary

\begin{tabular}{cccccccccc}
\hline & & & & \multicolumn{4}{c}{ Change Statistics } \\
\cline { 7 - 9 } Model & $R$ & R Square & $\begin{array}{c}\text { Adjusted } \\
\text { R Square }\end{array}$ & $\begin{array}{c}\text { Std. Error of } \\
\text { the Estimate }\end{array}$ & $\begin{array}{c}\text { R Square } \\
\text { Change }\end{array}$ & F Change & df1 & df2 & $\begin{array}{c}\text { Sig. F } \\
\text { Change }\end{array}$ \\
\hline 1 & $0,352^{a}$ & 0,124 & 0,117 & 7,61250 & 0,124 & 16,589 & 1 & 117 & 0,000 \\
\hline
\end{tabular}

a. Predictors: (Constant), X1

b. Dependent Variable: $Y$

Berdasar Tabel 7 nilai $r$ korelasi menunjukkan angka 0,352. Ini menunjukkan bahwa profesionalisme memiliki hubungan dengan kinerja guru sebesar 35,2\%. Pada 
kolom $\mathrm{r}$ square $\left(\mathrm{r}^{2}\right)$ menunjukkan angka 0,124 , hal tersebut menunjukkan bahwa kinerja guru dipengaruhi oleh variabel profesionalisme guru sebesar 12,4\%. Adapun pada kolom Adjusted $r^{2}$ menunjukkan angka 0,117, artinya bahwa profesionalisme guru mampu menjelaskan pengaruhnya secara nyata terhadap kinerja guru sebesar $11,7 \%$ dan sisanya; $100 \%-11,7 \%=88,3 \%$ dijelaskan oleh variabel yang lain.

Tabel 8. Analisis Coefficients Hipotesis

\section{Pertama}

\section{Coefficients}

\begin{tabular}{|c|c|c|c|c|c|}
\hline \multirow[b]{2}{*}{ Model } & \multicolumn{2}{|c|}{$\begin{array}{l}\text { Unstandardized } \\
\text { Coefficients }\end{array}$} & \multirow{2}{*}{$\begin{array}{c}\begin{array}{c}\text { Standardized } \\
\text { Coefficients }\end{array} \\
\text { Beta }\end{array}$} & \multirow{2}{*}{$\mathrm{T}$} & \multirow{2}{*}{ Sig. } \\
\hline & B & $\begin{array}{l}\text { Std. } \\
\text { Error }\end{array}$ & & & \\
\hline 1 (Constant) & 37,317 & 9,202 & & 4,055 & 0,000 \\
\hline X1 & 0,570 & 0,140 & 0,352 & 4,073 & 0,000 \\
\hline
\end{tabular}

a. Dependent Variable: $Y$

Pada tabel 8 pada kolom B bahwa nilai konstanta sebesar 37,317 sedangkan nilai Beta sebesar 0,352. Nilai tersebut bila dimasukkan dalam persamaan adalah sebagai berikut.

$$
\hat{Y}=37,317+0,352 X_{1}
$$

Hal tersebut menunjukkan bahwa profesionalitas SMK Negeri di ring utara ketika tidak ada pengaruh apapun memiliki nilai 37,317 .

Uji Hipotesis kedua

Terdapat pengaruh kepuasan kerja terhadap kinerja guru. Berdasar Tabel 9 nilai $\mathrm{r}$ korelasi menunjukkan angka 0,346. Ini menunjukkan bahwa kepuasan kerja memiliki hubungan dengan kinerja guru sebesar $34,6 \%$. Pada kolom $r$ square $\left(r^{2}\right)$ menunjukkan angka 0,120, hal tersebut menunjukkan bahwa kinerja guru dipengaruhi oleh variabel kepuasan kerja guru sebesar $12,0 \%$. Adapun pada kolom Adjusted $r^{2}$ menunjukkan angka 0,112, artinya bahwa kepuasan kerja guru mampu menjelaskan pengaruhnya secara nyata terhadap kinerja guru sebesar $11,2 \%$.

Tabel 9. Model Summary Hipotesis Kedua

Model Summary ${ }^{b}$

\begin{tabular}{cccccccccc}
\hline Model & $\mathrm{R}$ & $\begin{array}{c}\mathrm{R} \\
\text { Square }\end{array}$ & $\begin{array}{c}\text { Adjusted R } \\
\text { Square }\end{array}$ & $\begin{array}{c}\text { Std. Error of } \\
\text { the Estimate }\end{array}$ & $\begin{array}{c}\text { R Square } \\
\text { Change }\end{array}$ & F Change & df1 & df2 & $\begin{array}{c}\text { Sig. F } \\
\text { Change }\end{array}$ \\
\hline 1 & $0,346^{\mathrm{a}}$ & 0,120 & 0,112 & 7,63075 & 0,120 & 15,951 & 1 & 117 & 0,000 \\
\hline
\end{tabular}

a. Predictors: (Constant), X2

b. Dependent Variable: $Y$

Tabel 10. Analisis Coefficients Hipotesis Kedua

\begin{tabular}{|c|c|c|c|c|c|}
\hline \multirow[b]{3}{*}{ Model } & \multicolumn{3}{|c|}{ Coefficients $^{a}$} & \multirow[b]{3}{*}{$\mathrm{T}$} & \multirow[b]{3}{*}{ Sig. } \\
\hline & \multicolumn{2}{|c|}{$\begin{array}{l}\text { Unstandardize } \\
\text { d Coefficients }\end{array}$} & \multirow{2}{*}{$\begin{array}{c}\begin{array}{c}\text { Standardized } \\
\text { Coefficients }\end{array} \\
\text { Beta }\end{array}$} & & \\
\hline & B & $\begin{array}{l}\text { Std. } \\
\text { Error }\end{array}$ & & & \\
\hline 1 (Constant) & 47,474 & 6,850 & & 6,930 & 0,000 \\
\hline $\mathrm{X} 2$ & 0,558 & 0,140 & 0,346 & 3,994 & 0,000 \\
\hline
\end{tabular}

a. Dependent Variable: $\mathrm{Y}$

Dari analisis Coefficients bisa dijelaskan bahwa nilai konstanta sebesar 47,474 sedangkan nilai Beta sebesar 0,346 bila di- masukkan dalam persamaan regresi adalah sebagai berikut.

$$
\hat{\mathrm{Y}}=47,474+0,346 \mathrm{X}_{2}
$$

Persamaan tersebut memiliki makna bahwa kinerja guru memiliki nilai sebesar 47,474 ketika tidak mendapat pengaruh dari kepuasan kerja guru. Adapun ketika mendapat pengaruh kepuasan kerja guru setiap satu-satuan maka akan meningkat sebesar 0,346 .

\section{Hipotesis Ketiga}

Terdapat pengaruh iklim organisasi terhadap kinerja guru. 
Tabel 11. Model Summary Hipotesis Ketiga

Model Summary ${ }^{b}$

\begin{tabular}{ccccccccccc}
\hline & & & & & \multicolumn{5}{c}{ Change Statistics } \\
\cline { 6 - 10 } Model & $\mathrm{R}$ & $\begin{array}{c}\mathrm{R} \\
\text { Square }\end{array}$ & $\begin{array}{c}\text { Adjusted } \\
\mathrm{R} \text { Square }\end{array}$ & $\begin{array}{c}\text { Std. Error of } \\
\text { the Estimate }\end{array}$ & $\begin{array}{c}\text { R Square } \\
\text { Change }\end{array}$ & F Change & df1 & df2 & $\begin{array}{c}\text { Sig. F } \\
\text { Change }\end{array}$ \\
\hline 1 & $0,277^{a}$ & 0,077 & 0,069 & 7,81572 & 0,077 & 9,732 & 1 & 117 & 0,002 \\
\hline
\end{tabular}

a. Predictors: (Constant), X3

b. Dependent Variable: $Y$

Berdasar tabel 11 nilai $\mathrm{r}$ korelasi menunjukkan angka 0,277. Ini menunjukkan bahwa iklim organisasi memiliki hubungan dengan kinerja guru sebesar 27,7\%. Pada kolom $r$ square $\left(\mathrm{r}^{2}\right)$ menunjukkan angka 0,077, hal tersebut menunjukkan bahwa kinerja guru dipengaruhi oleh variabel iklim organisasi sebesar 7,7\%. Adapun pada kolom Adjusted $r^{2}$ menunjukkan angka 0,069, artinya bahwa iklim organisasi mampu menjelaskan pengaruhnya secara nyata terhadap kinerja guru sebesar 6,9\%.

Tabel 12. Analisis Coefficients Hipotesis Ketiga

\section{Coefficientsa}

\begin{tabular}{|c|c|c|c|c|c|}
\hline \multirow[b]{2}{*}{ Model } & \multicolumn{3}{|c|}{ Unstandardized Standardized } & \multirow[b]{2}{*}{$\mathrm{t}$} & \multirow[b]{2}{*}{ Sig. } \\
\hline & B & $\begin{array}{l}\text { Std. } \\
\text { Error }\end{array}$ & Beta & & \\
\hline 1 (Constant) & 57,097 & 5,684 & & 10,044 & 0,000 \\
\hline $\mathrm{X} 3$ & 0,634 & 0,203 & 0,277 & 3,120 & 0,002 \\
\hline
\end{tabular}

a. Dependent Variable: $Y$

Dari analisis Coefficients tabel bisa dijelaskan bahwa nilai konstanta sebesar
57,097 sedangkan nilai Beta sebesar 0,277 bila dimasukkan dalam persamaan regresi adalah sebagai berikut: $\hat{Y}=57,097+0,277 X_{3}$

Persamaan tersebut memiliki makna bahwa kinerja guru memiliki nilai sebesar 57,097 ketika tidak mendapat pengaruh dari iklim organisasi. Adapun ketika mendapat pengaruh iklim organisasi setiap satu-satuan maka akan meningkat sebesar 0,277 .

Kolom Sig menunjukkan angka 0,002, hal itu berarti bahwa variabel iklim organisasiberpengaruh terhadap kinerja guru, karena nilai Sig 0,002 jauh lebih kecil daripada nilai probabilitas 0,05. Dengan demikian hipotesis ketiga yang menyatakan bahwa iklim organisasi berpengaruh terhadap kinerja guru.

Hipotesis keempat

Terdapat pengaruh antara profesionalisme guru, kepuasan kerja guru dan iklim organisasi secara bersama-sama terhadap kinerja guru.

\section{Tabel 13. Model Summary Hipotesis Keempat}

Model Summary $b$

\begin{tabular}{|c|c|c|c|c|c|c|c|c|c|c|}
\hline \multirow[b]{2}{*}{ Model } & \multirow[b]{2}{*}{$\mathrm{R}$} & \multirow{2}{*}{$\begin{array}{c}\mathrm{R} \\
\text { Square }\end{array}$} & \multirow{2}{*}{$\begin{array}{l}\text { Adjusted } \\
\text { R Square }\end{array}$} & \multirow{2}{*}{$\begin{array}{l}\text { Std. Error of } \\
\text { the Estimate }\end{array}$} & \multicolumn{5}{|c|}{ Change Statistics } & \multirow{2}{*}{$\begin{array}{l}\text { Durbin- } \\
\text { Watson }\end{array}$} \\
\hline & & & & & $\begin{array}{l}\text { R Square } \\
\text { Change }\end{array}$ & F Change & df1 & df2 & $\begin{array}{l}\text { Sig. F } \\
\text { Change }\end{array}$ & \\
\hline 1 & $0,472^{a}$ & 0,223 & $\mathrm{O}, 202$ & 7,23337 & 0,223 & 10,987 & 3 & 115 & 0,000 & 1,951 \\
\hline
\end{tabular}

a. Predictors: (Constant), X3, X2, X1

b. Dependent Variable: $\mathrm{Y}$ 
Berdasar tabel nilai $\mathrm{R}$ korelasi menunjukkan angka 0,472. Ini menunjukkan bahwa profesionalisme guru, kepuasan kerja dan iklim organisasi secara bersamasama memiliki hubungan dengan kinerja guru sebesar $47,2 \%$. Pada kolom $R$ square $\left(R^{2}\right)$ menunjukkan angka 0,223 , hal tersebut menunjukkan bahwa kinerja guru dipengaruhi oleh variabel profesionalisme guru, kepuasan kerja guru dan iklim organisasi sebesar 22,3\%. Adapun pada kolom Adjusted $R^{2}$ menunjukkan angka 0,202 , artinya bahwa profesionalisme guru, kepuasan kerja guru dan iklim organisasi mampu menjelaskan pengaruhnya secara nyata terhadap kinerja guru sebesar $20,2 \%$.

Tabel 14. Analisis Regresi $X_{1}, X_{2}$ dan $X_{3}$ dengan $Y$ Analisis Coefficients Hipotesis Keempat

Coefficients $^{a}$

\begin{tabular}{lrrrrr}
\hline \multicolumn{7}{c}{$\begin{array}{c}\text { Unstandardized } \\
\text { Coefficients }\end{array}$} \\
& \multicolumn{2}{c}{$\begin{array}{c}\text { Standardized } \\
\text { Coefficients }\end{array}$} \\
Model & B & \multicolumn{1}{c}{ Error } & Beta & \multicolumn{1}{c}{ t } & Sig. \\
\hline 1(Constant) & 16,996 & 10,241 & & 1,660 & 0,100 \\
X1 & 0,438 & 0,139 & 0,271 & 3,150 & 0,002 \\
X2 & 0,427 & 0,139 & 0,265 & 3,079 & 0,003 \\
X3 & 0,293 & 0,202 & 0,128 & 1,453 & 0,149 \\
\hline
\end{tabular}

a. Dependent Variable: $Y$

Dari analisis Coefficients bisa dijelaskan bahwa nilai konstanta sebesar 16,996 sedangkan nilai Beta sebesar 0,271, 0,265, 0,128 bila dimasukkan dalam persamaan regresi adalah sebagai berikut:

$\hat{Y}=16,996+0,271 X_{1}+0,265 X_{2}+0,128 X_{3}$

Persamaan tersebut memiliki makna bahwa kinerja guru memiliki nilai sebesar 16,996 ketika tidak mendapat pengaruh dari profesionalisme guru, kepuasan kerja dan iklim organisasi secara bersama-sama.

Pengaruh Profesionalitas Guru terhadap Kinerja Guru

Adanya sikap profesional seorang guru dalam menjalankan ketugasannya, berpengaruh terhadap pelaksanaan kinerja seorang guru. Oleh karena itu guru memang berkewajiban untuk memiliki sikap profesionalitas. Sikap ini akan menuntun guru pada kualitas maupun kuantitas kinerja guru dalam menjalankan tugas. Guru yang profesional sangat dibutuhkan dimanapun dan kapanpun. Tanpa adanya guru yang profesional, pembelajaran akan berjalan seadanya dan jauh dari tujuan yang ditetapkan.

Dari hasil penelitian ini menunjukkan bahwa profesionalitas guru memiliki hubungan yang signifikan terhadap kinerja guru. Hal tersebut ditunjukkan nilai $r$ statistik sebesar 0,352 atau 35,2\%. Adapun $r$ determinasi menunjukkan angka 0,124 atau $12,4 \%$. Hal ini menunjukkan bahwa memang sikap profesional memiliki pengaruh terhadap kinerja guru

Pengaruh Kepuasan Kerja terhadap Kinerja Guru

Kepuasan kerja dalam pekerjaan adalah kepuasan kerja yang dinikmati dalam pekerjaan dengan memperoleh pujian hasil kerja, penempatan, perlakuan, peralatan, dan suasana lingkungan kerja yang baik. Karyawan yang baik suka menikmati kepuasan kerja dalam pekerjaan akan lebih mengutamakan pekerjaannya dari pada balas jasa walaupun balas jasa itu penting.

Kepuasan kerja guru akan berpengaruh bagaimana seorang guru menjiwai pekerjaan sehingga kinerjanya bisa meningkat. Kepuasan kerja menjadi penting agar rasa kepemilikan dan guru akan melakukan pekerjaannya dengan penuh semangat. Guru yang memiliki tingkat kepuasan yang tinggi akan selalu berusaha menjaga kapuasan kerja untuk meningkatkan kinerja. Kinerja yang maksimal merupakan dambaan setiap guru yang profesional.

Dari hasil penelitian ini menunjukkan bahwa kepuasan kerja guru memiliki hubungan yang signifikan terhadap kinerja guru. Hal tersebut ditunjukkan nilai $r$ statistik sebesar 0,346 atau 34,6\%. Adapun $\mathrm{r}$ determinasi menunjukkan angka 0,112 atau $11,2 \%$. Hal ini menunjukkan bahwa memang kepuasan kerja memiliki pengaruh terhadap kinerja guru. 
Pengaruh Ikilim Organisasi terhadap Kinerja Guru

Secara teori iklim organisasi adalah penilaian pada suasana atau lingkungan kerja dalam penilaian dan persepsi dalam hal: (1) struktur organisasi, bagaimana kepengurusan disusun dan ketepatan penempatan orang per orang sesuai dengan kapasitasnya (2) gaya kepemimpinan, bagaimana seorang kepala bergaul dan memperlakukan anak buahnya, apakah menyenangkan dan tampak akrab atau bersikap diktator, dan (3) hubungan antar personil, tingkat komunikasi mencerminkan sejauhmana antar personal memiliki hubungan yang baik dan bagaimana iklim organisasi terbentuk di suatu lingkungan.

Dari hasil penelitian ini menunjukkan bahwa iklim organisasi memiliki hubungan yang signifikan terhadap kinerja guru. Hal tersebut ditunjukkan nilai $r$ statistik sebesar 0,277 atau 27,7\%. Adapun $r$ determinasi menunjukkan angka 0,077 atau $7,7 \%$. Hal ini menunjukkan bahwa memang iklim organisasi memiliki pengaruh terhadap kinerja guru.

Pengaruh Profesionalisme Guru, Kepuasan Kerja Guru dan Iklim Organisasi secara Bersama-sama terhadap Kinerja Guru.

Faktor profesionalitas, kepuasan kerja dan iklim organisasi yang dilaksanakan dan dirasakan oleh seorang guru menjadi pedoman dalam mengembangkan kinerja. Yang mana, kepala sekolah menjadikannya sebagai dasar untuk memberikan tugas dan kewenangan. Karena keberpengaruhan tiga variabel yang dominan tersebut, berarti semakin bagus intensitas tingkat pelaksanaan ketiganya akan semakin meningkatkan kinerja seorang guru. Sebagaimana hasil analisis secara statistik, bahwa profesionalitas guru, kepuasan kerja dan iklim organisasi ini berpengaruh terhadap kinerja guru.

Sebagaimana hasil analisis regresi secara parsial, dari hasil penelitian ini menunjukkan bahwa profesionalitas kerja, kepuasan kerja dan iklim organisasi memiliki hubungan yang positif dan signifikan terhadap kinerja guru. Hal tersebut ditunjukkan nilai $\mathrm{R}$ statistik sebesar 0,472 atau $47,2 \%$. Adapun $\mathrm{R}$ determinasi menunjukkan angka 0,223 atau 22,3\%. Hal ini menunjukkan bahwa memang profesionalitas guru, kepuasan kerja dan iklim organisasi memiliki pengaruh terhadap kinerja guru.

Kinerja guru semakin meningkat dengan adanya beberapa faktor yang berkontribusi atau melatarbelakangi hasil tersebut. Semangat dan kesadaran serta supervisi yang berjalan lancar akan mendukung dalam mengimplementasikan semua variabel tersebut dengan leluasa, tanpa adanya paksaan. Kalau capaian-capaian itu terealisasi dengan beberapa paksaan, terlebih kalau menggunakan kekuatan untuk mempengaruhi anggota, maka pada ujungnya akan berakhir kekecewaan.

\section{Simpulan dan Saran}

Simpulan

Kinerja guru merupakan salah satu kunci sukses keberhasilan pelaksanaan pembelajaran di sekolah. Pembelajaran merupakan kunci pendidikan. Profesionalitas guru dalam bekerja merupakan kewajiban bagi setiap guru di sekolah. Dalam penelitian sikap profesionalitas guru berpengaruh terhadap kinerja guru dalam menjalankan tugasnya. Besarnya pengaruh profesionalitas terhadap kinerja guru adalah $12,4 \%$.

Bagaimanapun tantangan yang dihadapi guru dalam menjalankan tugasnya, guru memiliki kepuasan dalam bekerja. Kepuasan kerja yang dimiliki atau dirasakan oleh guru sangat berkaitan atau berhubungan dan berpengaruh terhadap kinerja guru. Sesuai hasil dalam penelitian ini, kepuasan kerja seorang guru berpengaruh terhadap kinerja guru dalam menjalankan ketugasan. Besarnya pengaruh kepuasan kerja terhadap kinerja guru adalah sebesar $11,2 \%$.

Selain profesionalitas guru dan kepuasan kerja guru, iklim organisasi atau iklim sekolah termasuk hal yang memiliki dampak terhadap kinerja guru. Pemimpin lembaga yang meperhatikan iklim organi- 
sasi memiliki kesempatan yang besar untuk meningkatkan kinerja guru di lingkungan lembaganya. Iklim organisasi mengkondusifkan semua karyawan dan guru untuk memiliki kinerja yang lebih baik. Dalam penelitian ini menunjukkan bahwa iklim organisasi berpengaruh terhadap kinerja yang dijalankan guru dalam ketugasan. Besarnya pengaruh iklim organisasi terhadap kinerja guru adalah sebesar $7,7 \%$.

Sikap profesionalitas guru, kepuasan kerja guru, dan iklim organisasi berpengaruh terhadap kinerja guru dalam menjalankan ketugasan. Besarnya pengaruh tersebut adalah $22,3 \%$.

\section{Saran}

Untuk meningkatkan kinerja guru perlu adanya peningkatan profesionalitas guru, kepuasan guru, dan iklim kerja dalam organisasi yang dinamis, disarankan beberapa hal sebagai berikut.

\section{Untuk Guru}

Secara aktif hendaknya guru melakukan upaya-upaya yang akan meningkatkan profesionalitasnya dalam menjalankan ketugasan. Upaya-upaya tersebut bisa dilakukan baik secara mandiri dengan mengikuti berbagai pelatihan atau seminar ataupun secara bersama-sama aktif dalam MGMP (Musyawarah Guru Mata Pelajaran).Guru hendaknya mengembangkan diri dalam mengajar sehingga mampu menciptakan kepuasan dan kebanggan diri dalam menjalankan tugas. Guru yang menyadari dan memahami ketugasannya akan memiliki kepuasan kerja yang baik.Hendaknya guru berupaya menciptakan iklim organisasi yang kondusif agar memiliki semangat kerja yang stabil. Iklim organisasi salah satunya diawali dari diri pribadi setiap guru. Oleh karena itu, guru perlu memiliki kesadaran dan kemauan yang kuat untuk menciptakan iklim organisasi yang kondusif dalam bekerja sehari-hari.

\section{Untuk Kepala Sekolah}

Kepala sekolah hendaknya selalu memantau dengan seksama perkembangan profesionalitas dan kepuasan kerja guru dalam menjalankan ketugasan.Kepala sekolah menindaklanjuti supervisi atau penilaian kinerja secara rutin dan berkala serta memberikan umpan balik kepada guru yang bersangkutan. Kepala sekolah hendaknya berupaya untuk menciptakan lingkungan kerja yang nyaman, kondusif, dan dinamis.

\section{Untuk Pengampu Kewenangan/Kebijakan}

Sikap profesionalitas guru selalu dipupuk dan ditingkatkan dengan adanya pelatihan dan pembinaan mental. Penilaian kinerja, hendaknya tidak sekedar formalitas penilaian terhadap guru, tetapi menjadi informasi yang positif dan strategis untuk peningkatan mutu pendidikan secara umum.

\section{Daftar Pustaka}

Chan, K. (2004). Teacher professional development: in-service teachers' motives, perceptions and concerns about teaching.Hongkong: Hong Kong Teachers' Centre Journal 《香港 教師中心學報》，Vol. 3. Diunduh tanggal 5 Maret 2014.

Damin, S. (2008). Kinerja staf dan organisasi. Bandung: Pustaka Setia.

Ghozali, I. (2001). Aplikasi analisis multivariate dengan program SPSS. Semarang: badan peneribitan universitas Diponegoro.

Hoy, W.K., \& Miskel, C.G. (2001). Educational administration, theory, research, and practice, six edition. New York: Random House.

Lunenburg, F.C \& Ornstein, A.C. (2000). Educational administration. Belmont: Wadsworth.

Mbah, S.E., Ikemefuna, C.E. (2012). Job Satisfaction and Employees' Turnover Intentions in total Nigeria plc. in Lagos State.International Journal of Humanities and Social Science.Vol. 2 No. 14 [Special Issue - July 2012.] 
McPheat, S. (2010). Emotional intelligence. London: MTD Training \& Ventus Publising ApS.

Muhammad, A. (2006). Komunikasi organisasi. Jakarta: Bumi Aksara.

Rusman.(2010). Model-model pembelajaran, mengembangkan profesionalisme guru. Jakarta: Rajawali Pers.

Snoek, M. (2012). Theories on and concepts of professionalism of teachers and their consequences for the curriculum in teacher education. http://www.hva. nl/kenniscentrum-doo/wpcontent/uploads/2012/04/
Theories-on-and-concepts-ofprofessionalism-Hungarianpublication.pdf. Diunduh tanggal 7 maret 2014.

Wahyudi, I. (2012). Pengembangan pendidikan, strategi inovatif dan kreatif dalam mengelola pendidikan secara komprehensif. Jakarta: Prestasi Pustaka.

Wirawan.(2008). Budaya dan iklim organisasi. Jakarta: Salemba Empat.

Yamin, M. (2007). Profesionalisasi guru $\mathcal{E}$ implementasi. Jakarta: Gaung Persada Press. 